\title{
Reflections of Gender Budget Initiatives in the Budgetary Allocations of Developed State in India: Kerala
}

\author{
P.U. Nishanthi \\ Assistant Professor, Department of Economics, Maharaja’s College, Ernakulam, Kerala, India. \\ E-mail: nishanthipu@gmail.com
}

\begin{abstract}
In this article tried to examine the changes made by gender budget initiative in the budgetary allocations of Kerala in terms of Women Specific Schemes (WSS). Deliberations made by the Govt. for mainstreaming budget by gender concerns are successful in terms of number of schemes and programmes and diversified programmes. Every year an increase in budgetary allocations could be seen but that increase is only in absolute terms. Percentage share of allocation towards the WSS are always oscillated under one percent. Govt. should go for gender budget initiatives by increasing percentage share of budgetary allocations. Govt. hadn't gone for exploiting the potential of gender budgeting. A stronger commitment from the Govt. is needed.

Keywords: Budgetary allocation, Gender budgeting, Gender equality, Women specific schemes, Women's welfare.
\end{abstract}

\section{INTRODUCTION}

Budgets have both microeconomic and macroeconomic effects on the economy. The effects of a government's budget on the individuals, society and on the economy are of great concern to economists, consumers and tax payers. Budget is the most important fiscal document relating to the socio-economic problems and programmes for the coming year which outlines the proposed measures of the government for their solution and implementation. The analysis of budgets would give the reflections of government policies on various heads especially on education, health and women's welfare. All the allocations have differential impact on class, community and gender. Since the budgets have differential impact on men and women or boys and girls budgets is not gender neutral. This necessitates analysis of the budget from a gender perspective. The gender issues needs to be studied and translated in to the policies, programmes and schemes of ministries and departments. This necessitates identification of existing policies, programmes and schemes to determine whether or not they meet these priority needs. Corrective reprioritisation of budgetary allocations and taking requisite follow-up actions can be ensured by adopting gender budgeting. Women are one of the backward sections of the society and needs special attention. Budgets at national and other levels are important mechanism for government to ensure women benefit from public sector expenditures.

Kerala has been attempting to 'mainstreaming gender' in the transformation of society through gender budgeting as an integral part of the planning process, with a much more expensive view on women's lives and roles they play not only in terms of their potential as paid workers but more importantly through invisibilised unpaid work in social reproduction and their vulnerability to violence (Gender \& Child Budget 2019-20, Govt. Kerala). An overall thrust in the 13th Five Year Plan is to make Planning and Budgeting gender sensitive with at least 10 percent of total outlay allocated for women specific schemes or schemes in which women's share is specified or identifiable based on gender disaggregated beneficiary data. The foremost objective of Gender Budgeting is to encourage all departments in the Government to become more gender aware and scrutinize their budgets from a gender perspective. It would, over the years, lead to an increase in budgetary priority for programmes and schemes designed specifically for women and girls, and efforts towards making composite public expenditure (which benefits both men and women) more responsive to gender concerns (Gender \& child Budget 2017-18, Govt. of Kerala). The govt. of Kerala is trying to sensitize all departments with women specific schemes (WSS) and pro women schemes as part of gender budget initiative. In this article tried to examine the changes made in the budgetary allocations in terms of WSS. The changes made by gender budget initiatives in the budget allocations of Kerala could be understood by analysing allocation towards WSS from 1957-58 to 2019-20.

\section{HISTORY OF GENDER BUDGET INITIATIVES IN KERALA}

Gender budgeting implies a gender based assessment of budgets, incorporating a gender perspective at all levels of the budgetary process and restructuring revenues and expenditures in order to promote gender equality. (Council of Europe, 2005). Initiative on gender responsive budgeting aims at categorisation of specific schemes and programmes which are stated to have components on women and exact budget shares of these components. Gender Responsive Budgeting is to analyse how effectively govt. policies, programmes and budgetary allocations respond to the needs and concerns of the females.

Kerala, the south western state in India, was formed on $1^{\text {st }}$ November, 1956 and it was long after Indian Independence on $15^{\text {th }}$ August 1947. The first state budget was presented on $7^{\text {th }}$ of June 1957 for the financial year $1957-58$ by Sri .C. Achutha Menon, the then Finance Minister of Kerala, under 
the Chief Minister ship of Sri. E.M.S Namboothiripad. Kerala had initiated the gender budgeting process at the local Government level as far back in 1998 and mandated the local bodies to allocate at least $10 \%$ of the plan funds devolved by the state specifically for women as part of Women Component Plan. The state budget started to reflect the gender budgeting process from 2008- 09 onwards. A concerted approach to make gender visible in every sector of the economy was formulated during this period. Gender Audit was initiated in Kerala as part of budget preparation and that exercise for the first time was done on the 2008-09 Kerala budget. In the budget 2010-11, the then finance minister has made a conscious effort to be gender responsive. Finance Minister stated that it is necessary to carry forward the traditions of social and economic egalitarianism in the State. In order to galvanise efforts towards this objective, gender budgeting is a must. All departments have tried to develop special schemes for the benefit of women. Efforts would be made to consciously incorporate gender concerns even in the general projects. (Budget Speech, Government of Kerala, 2010-11).

In the budget speech of 2011-12 also, gender budget initiatives continued. In May 2011 the then finance Minister continued what the previous Govt. did for gender budgeting for that particular financial year and for the following years. In 2016-17 new government came in to power and decided to reintroduce the gender budget initiatives .Finance minister stated before Assembly that the Government is going to reintroduce gender budgeting and hereafter, gender audit report will also be distributed to the honourable members along with budget documents. Apart from ensuring gender equality, $10 \%$ of the outlay will be set apart for women specific projects. According to finance minister "a new Department will be created for women. This department will be responsible for coordinating gender auditing and schemes related to women in other departments in addition to the schemes directly under this department”. (Budget Speech, Government of Kerala, 201617). From the year 2017-18 onwards a gender statement has been prepared by the State Planning Board distributed along with the budget document. In this statement, the allocations for women development have been divided into two parts. Part-A includes schemes for which $100 \%$ beneficiaries are women. The Part-B statement includes the general developmental schemes in which a special component for women or beneficiary number of women is distinguishable. Besides, in 2015, government formulated and approved 'Gender Equality and Women's Empowerment policy for Kerala 2014-2020 with a view to lay a basis for the harmonious coexistence of both sexes in society with equal access to economic, social and political opportunities, resources and benefits. This is the time-path of history of gender budget initiatives in Kerala.

\section{DATA SOURCES AND METHODOLOGY}

This study used secondary data. The changes made by gender budget initiatives in the budget allocation of Kerala have been analyzed in terms of women specific schemes and programmes (WSS). Women specific schemes are those schemes with $100 \%$ allocation towards women. Centrally sponsored women specific schemes /programmes also included. Allocation could be analyzed both in absolute and relative terms. In this study allocation towards WSS has been analysed in relative terms. Budget estimates are taken for analysis. Total outlay towards women specific schemes and programmes includes plan and non-plan expenditure. The period of study is from 1957-58 to 2019-20. Percentage share of WSS and women's welfare is calculated against total budget outlay and outlay towards WSS respectively. Secondary data collected from budget documents, plan documents etc...

\section{ALLOCATION TOWARDS WOMEN SPECIFIC SCHEMES/PROGRAMMES}

The state budget started to reflect the gender budgeting process from 2008- 09 onwards. The period from 2008-09 is a period of gender budget initiatives. During this period there were deliberations from the part of the government for including women specific schemes (WSS) and pro-women schemes in the budget. The study showed that during the period of gender budget initiative, departments having women specific schemes and the total numbers of schemes and programmes of these departments have increased. Out of 46 departments of the Government, 22 were there with women specific schemes and programmes. During this period total number of schemes and programmes reached to one hundred. The government was successful in sensitizing more departments with WSS. But, allocation towards WSS was always less than one per cent during gender budget initiative. This could be understood from the Table I

Perusal of the Table I show that there were allocations towards women specific schemes even before the period of gender budget initiatives. WWS was there in the budget right from the beginning, i.e., from the year 1958-59 onwards. From the year 1961- 62 there was continuous allocation towards WSS. In the beginning it was in the form of investment towards women's education. Community development projects, natural service, local development works under public health. In the year 197071 , the head 'women's welfare' appeared under the major head 'Harijan welfare'. Percentage share of WSS in total budget outlay before and during the budget initiatives would give that in terms of allocation there were change in the allocation but that change was oscillating under one percent. During the period of gender budget initiatives it could be noticed that the allocation towards WSS was only less than one percent. It was always fluctuating. It never went beyond one percent. Up to 1970-71 the allocation was very meager. The important thing is this, percentage share allocation towards the WSS before and during the years of gender initiatives remained less than one percent. This shows that even after the introduction of gender budget initiatives there were not much increase in the allocation towards WSS as the Govt. claims. 
TABLE I SHARE OF WOMEN SPECIFIC SCHEMES /PROGRAMMES

\begin{tabular}{|c|c|c|c|c|c|c|c|}
\hline YEAR & $\%$ share of WSS & YEAR & $\%$ share of WSS & YEAR & $\%$ share of WSS & YEAR & $\%$ share of WSS \\
\hline $1957-58$ & NIL & $1977-78$ & 0.39 & $1997-98$ & 2.40 & 2016-17 & 0.64 \\
\hline 1958-59 & NIL & $1978-79$ & 0.04 & 1998-99 & 0.11 & 2017-18 & 0.73 \\
\hline 1958-59 & 0.01 & $1980-81$ & 0.14 & 1999-00 & 0.20 & 2018-19 & 0.76 \\
\hline $1959-60$ & NIL & $1981-82$ & 0.19 & 2000-01 & 0.17 & $2019-20$ & 0.53 \\
\hline 1960-61 & NIL & $1982-83$ & 0.03 & 2001-02 & 0.17 & & \\
\hline 1961-62 & 0.009 & $1983-84$ & 0.19 & 2002-03 & 0.16 & & \\
\hline $1962-63$ & 0.01 & 1984-85 & 0.33 & 2003-04 & 0.49 & & \\
\hline $1963-64$ & 0.01 & $1985-86$ & 0.32 & 2004-05 & 0.24 & & \\
\hline 1964-65 & 0.01 & 1986-87 & 0.30 & 2005-06 & 0.25 & & \\
\hline $1965-66$ & 0.0001 & $1987-88$ & 0.43 & 2006-07 & 0.32 & & \\
\hline $1966-67$ & 0.0015 & 1988-89 & 0.35 & 2007-08 & 0.24 & & \\
\hline $1967-68$ & 0.0001 & 1989-90 & 0.20 & 2008-09 & 0.20 & & \\
\hline 1968-69 & 0.57 & $1990-91$ & 0.20 & 2009-10 & 0.23 & & \\
\hline $1970-71$ & 0.0083 & 1991-92 & 0.19 & 2010-11 & 0.32 & & \\
\hline $1971-72$ & 0.11 & $1992-93$ & 0.30 & 2011-12 & 0.52 & & \\
\hline $1972-73$ & 0.11 & 1993-94 & 0.22 & 2012-13 & 0.63 & & \\
\hline $1973-74$ & 0.15 & 1994-95 & 0.19 & 2013-14 & 0.62 & & \\
\hline $1975-76$ & 0.06 & 1995-96 & 0.16 & 2014-15 & 0.62 & & \\
\hline $1976-77$ & 0.09 & $1996-97$ & 2.32 & 2015-16 & 0.57 & & \\
\hline
\end{tabular}

Only in two years allocation exceeded more than one percent i.e., in the years 1996-97 and 1997-98. This argument will be reinforced by analyzing a major head i.e.,

\section{A. Women's Welfare}

There was a head exclusively for women's welfare from the year 1970-71 themselves in the budgetary allocations and continuing till the last budget. Govt. of Kerala has been implementing various schemes and programmes for the welfare of women under this head. This was under the head 'social welfare' up to 2008-09. Social welfare was a part of social welfare of SC, ST and OBC. From 2009-10 onwards women's welfare that comes under women specific schemes and programmes.

this head came under social security and welfare. From the year 1971-72 itself, Government of Kerala has been implementing schemes and programmes for the welfare of women through this head, even though the amount allocated to this head was very small. Perusal of the Table II shows that the values are fluctuating in a periodic manner. No increase in allocation could be seendue to the introduction of gender budget initiative. For the whole period it has been showing a wave like fluctuations. 
TABLE II SHARE OF WOMEN'S WELFARE IN WSS

\begin{tabular}{|l|c|c|c|c|c|}
\hline YEAR & $\begin{array}{c}\text { \% Share of } \\
\text { women's welfare } \\
\text { in WSS }\end{array}$ & YEAR & $\begin{array}{c}\text { \% Share of } \\
\text { women's welfare } \\
\text { in WSS }\end{array}$ & YEAR & $\begin{array}{c}\text { \% Share of women's } \\
\text { welfare in WSS }\end{array}$ \\
\hline $1971-72$ & 0.30 & $1988-89$ & 2.70 & $2005-06$ & 4.18 \\
\hline $1972-73$ & 0.19 & $1989-90$ & 2.88 & $2006-07$ & 3.21 \\
\hline $1973-74$ & 0.43 & $1990-91$ & 21.01 & $2007-08$ & 7.11 \\
\hline $1974-75$ & 7.49 & $1991-92$ & 7.32 & $2008-09$ & 9.99 \\
\hline $1975-76$ & 3.42 & $1992-93$ & 13.06 & $2009-10$ & 8.91 \\
\hline $1976-77$ & 2.85 & $1993-94$ & 12.79 & $2010-11$ & 35.01 \\
\hline $1977-78$ & 0.28 & $1994-95$ & 9.48 & $2011-12$ & 22.97 \\
\hline $1978-79$ & 3.21 & $1995-96$ & 0.71 & $2012-13$ & 12.99 \\
\hline $1979-80$ & 2.25 & $1996-97$ & 0.02 & $2013-14$ & 10.48 \\
\hline $1980-81$ & 4.52 & $1997-98$ & 3.00 & $2014-15$ & 6.86 \\
\hline $1981-82$ & 13.21 & $1998-99$ & 1.87 & $2015-16$ & 7.46 \\
\hline $1982-83$ & 02.14 & $1999-00$ & 5.46 & $2016-17$ & 8.90 \\
\hline $1983-84$ & 0.91 & $2000-01$ & 2.69 & $2017-18$ & 9.94 \\
\hline $1984-85$ & 0.76 & $2001-02$ & 3.15 & $2018-19$ & 12.17 \\
\hline $1985-86$ & 1.18 & $2002-03$ & 4.91 & $2019-20$ & 12.68 \\
\hline $1986-87$ & 2.67 & $2003-04$ & 5.01 & & \\
\hline $1987-88$ & 1.79 & $2004-05$ & 4.84 & & \\
\hline & & & Source: Budget Documents, Government of Kerala, India. \\
\hline
\end{tabular}

\section{B. Schemes and Programmes under Women's Welfare}

The change in the budgetary allocations could also be analysed in terms of schemes and programmes under the head women's welfare. Table III (a) \& III (b) shows the programmes and schemes under women's welfare from 1971-72 to $1989-90$ and $1990-91$ to 2007-08 respectively. Perusal of the table III (a) \& (b) shows that women specific schemes and programmes were in the budget from 1970s itself but number of WSS was low and it was near to ten.

One of the important allocations made under this head was the contribution towards women's commission. Another contribution was towards social welfare board. The programmes come under women's welfare during the period were in the nature of welfare programmes, employment generation programmes, infrastructural facilities and financial assistance schemes. This shows that from 1970s itself, Govt. had been implementing programmes for the welfare and upliftment of the women.

Table IV shows the programmes and schemes during the period of gender budget initiatives. During this period numbers of programmes in each year have increased. Schemes and programmes were diversified, and these programmes were meeting different needs of women. This diversification and increase in number of schemes and programmes are the outcome of the gender budget initiative in Kerala. Govt. was successful in mainstreaming gender concerns by increasing and diversifying the women specific programmes. Schemes and programmes are gender awareness, financial assistance, health and nutrition, infrastructure, social security and livelihood generation.

The schemes and programmes are meeting the practical and strategic gender needs of women community. Some programmes are partially and fully sponsored by the central govt. Govt. tried to create gender awareness among the people. Govt. had diversified and increased number of programmes and schemes but that is the only change that could be the after effect of the gender budget initiatives. In absolute terms there has been increase in the allocation towards women specific schemes and programmes over the years. In relative terms it remained less than one percent. 
TABLE III (a) SCHEMES AND PROGRAMMES UNDER WOMEN'S WELFARE

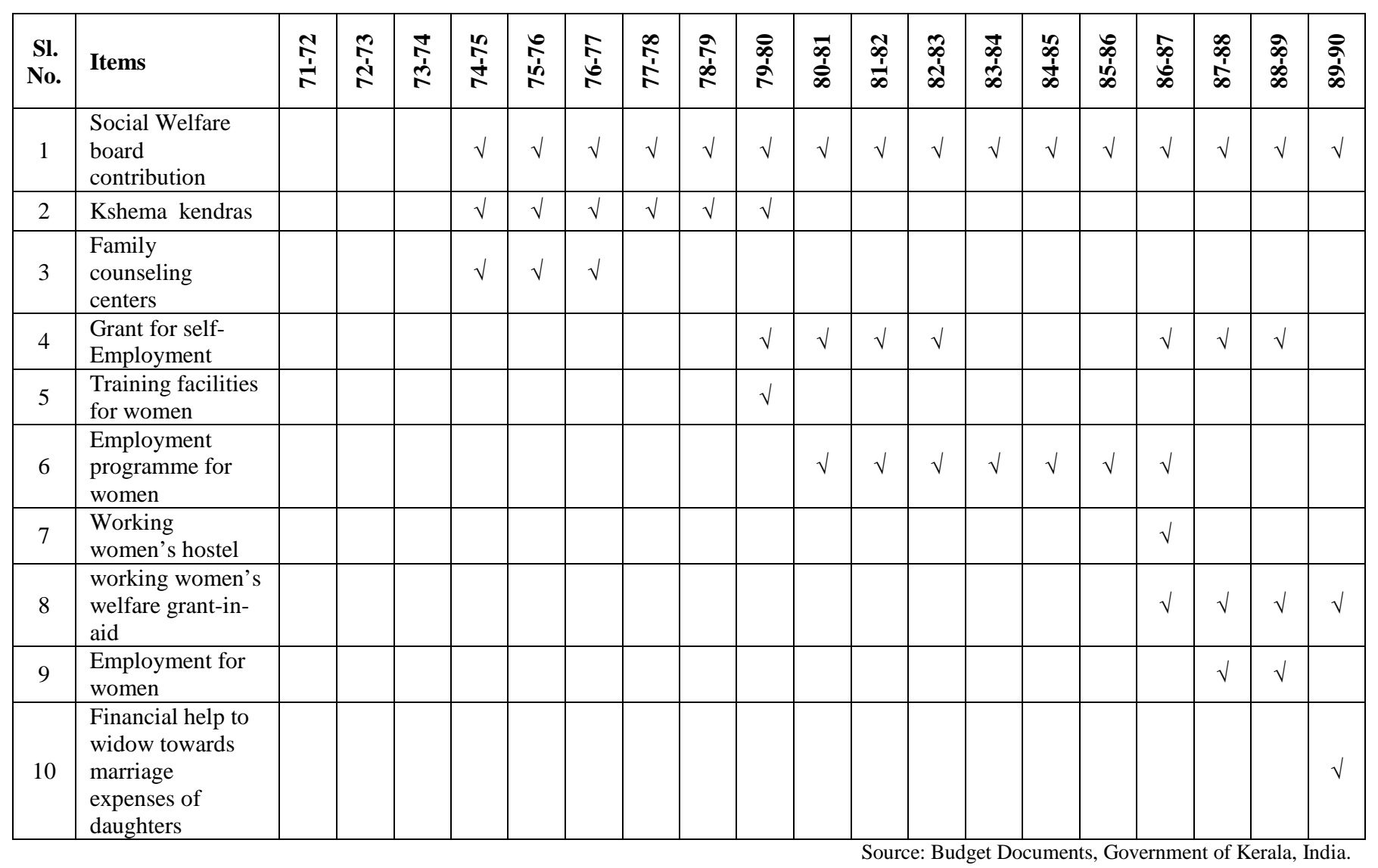

TABLE III (b) SCHEMES AND PROGRAMMES UNDER WOMEN'S WELFARE

\begin{tabular}{|c|c|c|c|c|c|c|c|c|c|c|c|c|c|c|c|c|c|c|}
\hline $\begin{array}{l}\text { Sl } \\
\text { No. }\end{array}$ & Items & के & \%ै & $\begin{array}{l}\text { \% } \\
\text { ஸे }\end{array}$ & $\begin{array}{l}\text { के } \\
\text { ตे }\end{array}$ & 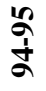 & $\begin{array}{l}\text { के } \\
\text { ட் }\end{array}$ & के & \begin{tabular}{l}
$\infty$ \\
\multirow{1}{1}{} \\
ó
\end{tabular} & $\begin{array}{l}\text { के } \\
\text { के } \\
\text { के }\end{array}$ & $\begin{array}{l}\text { ò } \\
\text { ò } \\
\text { o }\end{array}$ & ָ̊ & $\begin{array}{l}\text { ? } \\
\stackrel{1}{\alpha} \\
\text { ช }\end{array}$ & $\begin{array}{l}\text { ठ̀ } \\
\text { ભิ }\end{array}$ & $\begin{array}{l}\text { Lo } \\
\text { ô } \\
\text { t̀ }\end{array}$ & 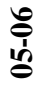 & $\begin{array}{l}\hat{o} \\
\vdots \\
0\end{array}$ & $\begin{array}{l}\infty \\
\stackrel{1}{1} \\
\text { ஸे }\end{array}$ \\
\hline 1 & $\begin{array}{l}\text { Social welfare board } \\
\text { contribution }\end{array}$ & $\sqrt{ }$ & $\sqrt{ }$ & $\sqrt{ }$ & $\sqrt{ }$ & $\sqrt{ }$ & $\sqrt{ }$ & $\sqrt{ }$ & $\sqrt{ }$ & $\sqrt{ }$ & $\sqrt{ }$ & $\sqrt{ }$ & $\sqrt{ }$ & $\sqrt{ }$ & $\sqrt{ }$ & $\sqrt{ }$ & $\sqrt{ }$ & $\sqrt{ }$ \\
\hline 2 & $\begin{array}{l}\text { Grant for self- } \\
\text { employment }\end{array}$ & $\sqrt{ }$ & & & & & & & & & & & & & & & & \\
\hline 3 & $\begin{array}{l}\text { Employment } \\
\text { programme for women }\end{array}$ & $\sqrt{ }$ & & & & & & & & & & & & & & & & \\
\hline 4 & $\begin{array}{l}\text { Financial help to } \\
\text { widow towards } \\
\text { Marriage Expenses of } \\
\text { Daughters }\end{array}$ & $\sqrt{ }$ & $\sqrt{ }$ & $\sqrt{ }$ & $\sqrt{ }$ & $\sqrt{ }$ & $\sqrt{ }$ & & & & & & & & & & & \\
\hline 5 & $\begin{array}{l}\text { Statutory Women’s } \\
\text { Commission }\end{array}$ & $\sqrt{ }$ & $\sqrt{ }$ & $\sqrt{ }$ & $\sqrt{ }$ & $\sqrt{ }$ & $\sqrt{ }$ & $\sqrt{ }$ & $\sqrt{ }$ & $\sqrt{ }$ & $\sqrt{ }$ & $\sqrt{ }$ & $\sqrt{ }$ & $\sqrt{ }$ & $\sqrt{ }$ & $\sqrt{ }$ & $\sqrt{ }$ & $\sqrt{ }$ \\
\hline 6 & $\begin{array}{l}\text { Self-Employment. } \\
\text { Scheme for Women in } \\
\text { Distress }\end{array}$ & & & $\sqrt{ }$ & $\sqrt{ }$ & $\sqrt{ }$ & & & & & & & & & & & & \\
\hline
\end{tabular}


TABLE IV SCHEMES AND PROGRAMMES UNDER WOMEN'S WELFARE

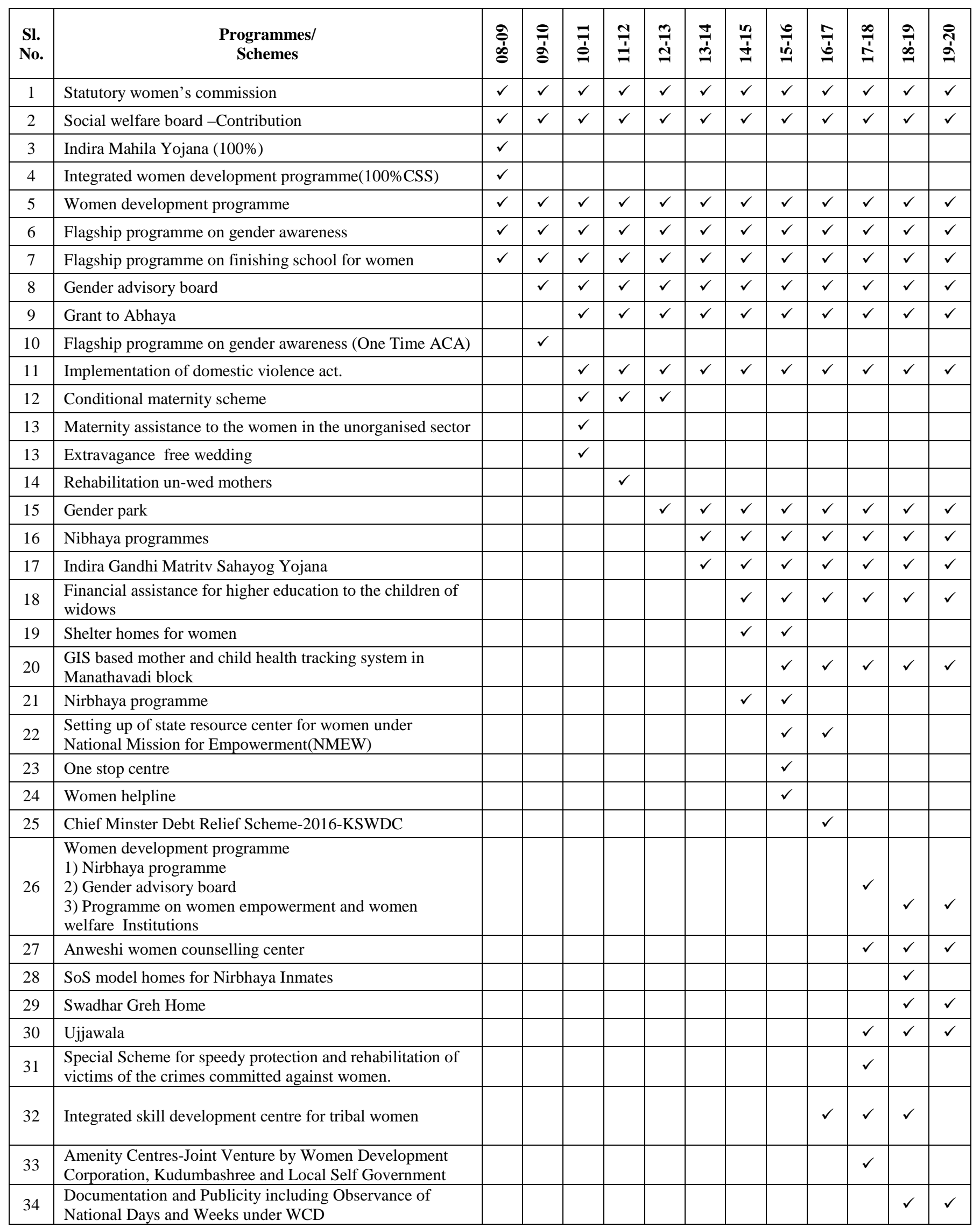




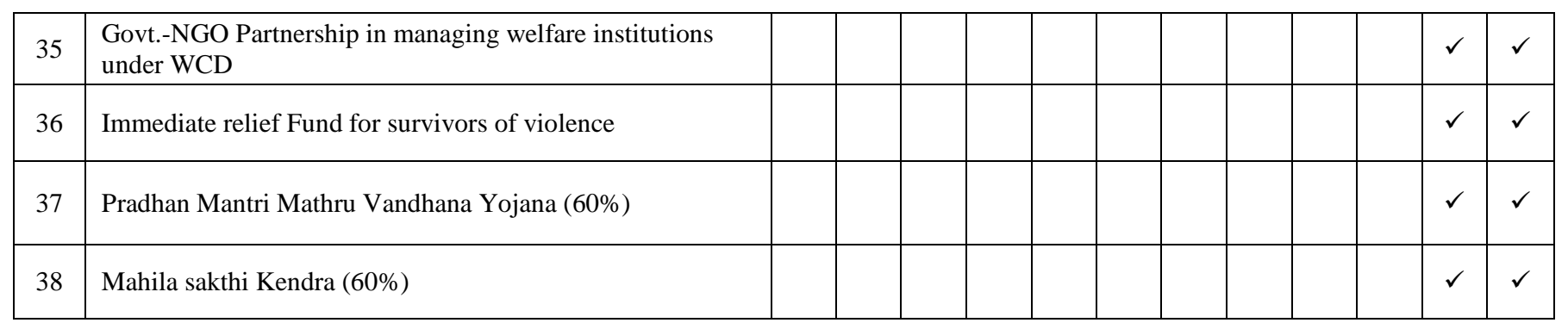

Source: Budget Documents, Government of Kerala, India.

\section{CONCLUSION}

The Govt. of Kerala has been successful in mainstreaming budget by gender concerns. Govt. tried to develop special schemes and programmes for the benefit of women. Efforts have made consciously to incorporate gender concern even in the general project. But this study shows that allocations during the period of gender budget initiatives is as before as in the period of pre-gender budget initiatives. Deliberations made by the Govt. for mainstreaming budget by gender concerns are successful in terms of number of schemes and programmes and diversification of the same. Percentage share of allocation towards the WSS always oscillated under one percent in both the period. Govt. is successful in increasing and diversifying the women specific schemes and programmes but the percentage share of WSS remained without much change during both the periods.

To conclude gender budget initiative brought not much change in terms of allocation. Gender budget initiatives are in terms of changes in the number of schemes and programmes and not in terms of allocation. Number of schemes and programmes has increased but percentage share of allocation remained same for all years. Govt. should go for gender budget initiatives by increasing percentage share of budgetary allocations. Govt. hadn't gone for exploiting the potential of gender budgeting. A stronger commitment from the Govt. is needed.

\section{REFERENCES}

[1] Council of Europe, (2005). Gender Budgeting, Directorate of Human Rights, Strasbourg, France.

[2] Finance Department, (1958-2019).Budget Documents, Government of Kerala, Trivandrum.

[3] Finance Department, (2017-20). Gender \&Child Budget, Government of Kerala, Trivandrum.

[4] Finance Department, (2010-11). Budget Speech, Government of Kerala, Trivandrum.

[5] Finance Department, (2016-17).Budget Speech, Government of Kerala, Trivandrum.

[6] Kerala State Planning Board, (2012). Gender Equality in Kerala: A Quick Study Report, Ernakulum Division, Government of Kerala, Trivandrum.

[7] Planning \&Economic Affairs Department, (2012). Plan Documents, Government of Kerala, Trivandrum. 